21. The Economic Impact of U.S. Sanctions with Respect to Cuba. U.S International Trade Commission. [Online] Available from: https://books.google.com.ua/books?id=c0wCioRlTG0C\&pg=SA2PA2\&redir_esc $=\mathrm{y} \# \mathrm{v}=$ onepage \&q\&f=false (in English). [Accessed: 01.01.2018].

22. Vasilieva O. (2004). Russkaja Pravoslavnaja Tserkov i II Vatikanskoi sobor [Russian Orthodox Church and the Second Vatican Council]. M.: Lepta. (in Russian).

Надійшла до редколегії 27.04.2018 Ukraine

Ivan Danyliuk, Graduate Student Taras Shevchenko National University of Kyiv, Kyiv,

\title{
DIPLOMACY OF THE HOLY SEE IN SOLVING THE CARIBBEAN CRISIS
}

Abstract. The article considers the role of the Holy See and the Catholic Church in solving the Cuban crisis of 1962 through the activities of Pope John XXIII.

The article considers the reasons and the beginning of the Caribbean crisis. A short chronology of the events which led to the crisis is presented: from the break of the Cuban Revolution of 1959 and intensifying relations between Havana and Washington to the sharpening thereof between the USA and the USSR in the Caribbean region during October 1962.

The article analyzes the activities of Pope John XXIII in solving the Caribbean crisis of 1962 and presents the message and his appeals to the leaders of the USA and the USSR during the peak of the Caribbean crisis. The assessment of Pope's actions during the crisis and their role in solving thereof are described.

The article lists feedbacks of the world's leaders towards the activities of Pope John XXIII, namely, the response to the message and appeals of Pope for peace from Nikita Khrushchev, John Kennedy etc.

The article provides the analysis of the Encyclical «Pacem in terris» published in April 1963. It emphasizes that the Encyclical is the answer to the crisis of war and is the first one covering the questions of war and peace.

In less than five years of pontificate, John XXIII was more than a reformer who convocated the Second Vatican Council and determined the face of the Catholic Church nowadays, but also a fighter for peace, therefore he was granted the name of "The Pope of Peace». John XXIII is also an example of the ability of a man of humble origins to execute huge moral influence on the most powerful men of the earth: for his actions during the missile crisis in Cuba, one of the biggest tension in the history of the Cold War, during which in the course of thirteen days from October 16 till October 28, 1962 - the world came to the brink of nuclear disaster. USSR.

Key words: the Cuban missile crisis, peace, war, diplomacy, Holy See, Cuba, the USA, the

УДК 327-047.27(73):(8)

http://doi.org/10.17721/2521-1706.2018.05.163-169
Катерина Вакарчук, кандидат політичних наук, доцент Одеський національний університет імені I. I. Мечникова

\section{ПОЛТТИКА АДМІНІСТРАЦЇ̈ Д. ТРАМПА ЩОДО КРАЇН ЛАТИНСЬКОЇ АМЕРИКИ: ПРОГНОЗИ ТА ПЕРСПЕКТИВИ}

Анотація. В статті розглянуто основні зміни зовнішньої політики США щуодо країн Латинської Америки при адміністращії Д.Трампа. Проаналізовано нові виклики та підходи щодо налагодження відносин між країнами Західної півкулі. Розглянуто основні 
візити до краӥн Латинської Америки представників нової адміністрачії США, зокрема Колумбї, Аргентини, Чилі та Панами. Ключовими питаннями в обговоренні лідерів країн та віце-президента США стали: вироблення спільної позицї по вирішенню кризи в Венесуелі та можливість військової інтервенщіі зі сторони США, питання безпеки, покращення торгово-економічного співробітництва та відновленні демократі в країнах Латинської Америки. Зроблено аналіз заяв, щэодо зміни політики США по відноменню до Мексики, стосується будівництва нового кордону у вигляді стіни між двома країнами, посилення мір щзодо міграчійної політики, перегляд угоди про Північноамериканську зону вільної торгівлі, та позицій в ній Мексики та Канади. Встановлення дипломатичних відносин, між Кубою та США зустріло різку критику з боку Д.Трама, зазначено, щзо він не буде продовжувати заявлену стратегію свого попередника, поки на острові не буде змінено керівництво, політичний режим краӥни та відновлено права і свободи громадян. Відбувається зміна у відносинах між Аргентиною та США у зв'язку з приходом нового президента Аргентини, відбулися офіиійні візити між президентами обох краӥн. Щодо Венесуели, це ключове питання, США шукає підтримки у лідерів континенту щуодо можливого військового втручання, 3 поки щзо різким засудженням 3 боку південноамериканських лідерів.

Ключові слова: США, Латинська Америка, зовнішня політика, відносини, перспективи.

Протягом тривалого часу регіон Латинської Америки знаходився на периферії світової політики, але вже сьогодні, завойовує своє місце в глобальній повістці дня. Пошук ролі в цьому нелегкому шляху важкий і тернистий, адже, майже 500 років колоніального управління, а потім статус «заднього двора Америки» зробили свою справу. Країни Латинської Америки мають унікальні цивілізаційні, культурні, просторові характеристики, і вивчення та дослідження цього регіону заслуговують пильної уваги з боку дослідників, вчених та науковців, що і надає актуальності обраної теми.

Серед російських вчених, можна виділити В. П. Сударева, П. П. Яковлева, Б. Ф. Мартинова, А.Н. Боровкова, Є. Астахова, їх роботи стосуються усіх напрямків латиноамериканістики $є$ грунтовними та змістовними у висвітленні питань міжнародних відносин та світової політики, і ролі латиноамериканських країн. Українська латиноамериканістика знаходиться на порозі становлення та формування, але можна виділити ряд дослідників, які цікавляться цією тематикою, і мають ряд робіт присвячених міжамериканській системі відносин, відносин між США та країнами Латинської Америки, і взагалі латиноамериканської тематики в цілому, такі як О. І. Ткач, Н. І. Шевченко, В. Г. Космина. Нові підходи адміністрації Д. Трампа, щодо зовнішньої політики в країнах Латинської Америки, статей висвітлені в статях американського дослідника Г. Уікса.

Метою даної статті є аналіз та розгляд перспектив відносин між США та країнами Латинської Америки в період президентства Д. Трампа.

20 січня 2017 року офіційно вступив на посаду 45-й президент США Дональд Трамп, його перемога стала для багатьох несподіванкою. Ряд лідерів країн Латинської Америки вже висловили своє занепокоєння і підкреслили, зокрема експрезидент Бразилії Д. Руссефф зауважила, що Трамп є катастрофою для всього латиноамериканського світу. Однак, як будуть розгортатись події далі, ми можемо тільки прогнозувати, чи буде сформована нова доктрина зовнішньої політики США стосовно країн Латинської Америки та якими будуть іiі наслідки, це питання найближчого майбутнього. 
Відносини зі своїм гегемоном були непростими, і починаючи з Доктрини Монро регіон розглядався на зовнішньополітичній арені, як невід'ємне ціле зі своїм північним сусідом. Ситуація кардинально міняється у XXI ст., ряд країн міняють модель управління, економічні показники зростають, а такі країни як Бразилія, Аргентина, Уругвай, Перу, Чилі все більше інтегруються в різноманітні об'єднання, МЕРКОСУР, УНАСУР, Андський Союз Націй та починають проводити самостійну зовнішню політику.

3 приходом кожного президента США до влади, так чи інакше змінювалися підходи зовнішньої політики відносно Латинської Америки, однак суть іiі залишалася майже однаковою, гегемоністська та патерналістська політика. Однак, зрушення та перегляд такої політики було здійснено Б. Обамою, який започаткував новий підхід у відносинах між США та Латинською Америкою, відносини стратегічного та рівноправного партнерства. Саме Б. Обама почав реалізовувати на практиці нову зовнішньополітичну доктрину, адаптовану до реалій XXI ст. i покликану дати відповідь на ключові міжнародні виклики [5].

В останнє десятиліття традиційно сильні позиції в США в Латинській Америці значно ослабли, поява в регіоні так званих лівих режимів, активізація


Китаю, та посилення свого інтересу з боку Росії. Всі ці явища сприяли тому, що латиноамериканський світ зустрів прихід до влади нового президента США в 2016 році $з$ деякою обачністю та недовірою. Адже, очікування від стратегії Б. Обами в регіоні не були виправдані, можна стверджувати про деяке розчарування його політикою. Перші виступи на посаді президент Д.Трамп почав із критики підходу Б. Обами щодо так званого «стратегічного партнерства» в країнах Південної Америки.

Адже, ще не сформована, а по суті і відсутня зовнішньополітична стратегія держави США, «доктрина Трампа» в Латинській Америці має два суттєвих елемента: перше, це сильна, а інколи воєнна риторична опозиція щодо політики адміністрації попереднього президента США, але одночасно, це і слідування стратегії Б. Обами, в поєднанні з погрозами змінити іiі. Така позиція нинішнього президента послаблює дипломатичну позицію адміністрації Д. Трампа в країнах Латинської Америки [6].

Влітку 2017 року віце-президент США М. Пенс почав так зване інспектування по країнам Латинської Америки. В своїх виступах зазначав, що всі країни, які входять до Західної півкулі являються пріоритетними для нашої адміністрації, а процвітання США залежить від процвітання Латинської Америки, і навпаки. Колумбія стала першою країною, яку відвідав М.Пенс, також він побував в Аргентині, Чилі та Панамі. Метою візиту, було проведення переговорів з чотирма країнами про ситуацію в Венесуелі, та вироблення спільної тактики та позиції у вирішенні кризи.

Зустріч з президентом Колумбії Х. Сантосом пройшла у форматі переговорів, щодо ситуації у Венесуелі, М. Пенс підкреслив, що США не виключає застосування військової інтервенції щодо Венесуели, на що Сантос зауважив, що і Колумбія і весь південноамериканський світ прагне мирного вирішення політичної кризи в Венесуелі, застосовуючи виключно, економічні та дипломатичні санкції. Адже, як підкреслив президент Колумбії, Південна Америка являється континентом миру, і всі країни хотіли б підтримати цей статус і у вирішенні питання щодо Венесуели. 
Наступною країною в рамках турне по країнам Латинської Америки стала Аргентина, і не випадково. Восени 2015 року в Аргентині пройшли вибори президента країни, ним став Маурісіо Макрі. Його перемога стала переломним моментом, і новою точкою відліку історії Аргентини, до цього у владі 12 років знаходилися Нестор та Кристина Кіршнер, і їхня модель управління привела до економічного краху країни, та заморожені американо - аргентинських відносин на десятиліття.

Ще до візиту Пейнса до Буенос-Айреса, країну відвідав Б. Обама, а потім і Дж. Керрі в 2016 році, цим самим показавши свою прихильність до обраного курсу Аргентини та відновлення дружніх відносини між країнами.

Віце-президент США Майк Пенс прибув в Аргентину з офіційним візитом 3 великою делегацією бізнесменів. Було обговорено значне коло питань, які стосувалися продуктивної взаємодії США з регіональними партнерами, питанням безпеки, торгово-економічного співробітництва та відновленні демократії в Аргентині та переходу до неоліберальної моделі розвитку країни. Про повернення Аргентини в «західний світ» красномовно засвідчили візити президента Франції Е. Макрона, канцлера Німеччини А. Меркель, прем'єр-міністра Італії до Буенос Айресу.

Ще одним важливим кроком у зближенні США та Аргентини, став офіційний візит Маурісіо Макрі до США 27 квітня 2017 року, де президенти обох країн провели особисту зустріч. Зустріч проходила у форматі обговорення ситуації на американському континенті в цілому, і Аргентині зокрема, також президент Аргентини зустрічався з членами адміністрації Білого Дому. В спільній заяві двох президентів було підтверджено готовність до співробітництва в економічній галузі, залучення американських інвестицій в Аргентину.

Щодо політичних поглядів нинішнього президента Аргентини, то він відомий своїми проамериканськими поглядами, після обрання на посаду, одразу заявив про зміну зовнішньополітичного курсу країни, де пріоритетними стануть відносини із США та Європою. Відомо, і про особисті контакти Макрі і Трампа в бізнесовому колі, і експерти відмічають схожість політичних портретів двох лідерів.

Наступною країною у турне М. Пенса було Чилі. Хотілося б відмити факт, що відбувся 23 січня 2017 року, підписання Д.Трампом указу про вихід із Транстихоокеанського партнерства, що означав припинення участі США в Транстихоокеанській торговій угоді між 12 країнами-учасниками. Це питання i стало предметом обговорення віце-президента США з послом Чилі в США, адже, на тісне співробітництво Чилі з Азіатсько-Тихоокеанським регіоном керівництво країни робить великі ставки. На брифінгі з президентом Чилі Мішель Бачелет, Майк Пенс закликав в м. Сантьяго такі країни як Чилі, Перу, Мексику та Бразилію розірвати дипломатичні та комерційні зв'язки з КНДР.

Ще одна країна, яка викликає занепокоєння у Білому Домі є Панама, являючись достатньо крупним американським торгівельним партнером, встановила дипломатичні відносини з Китаєм в 2017 році, тим самим посиливши роль Китаю в регіоні. Тому, візит М. Пенса до Панами стосувався виключно питань торгівлі та безпеки.

Також, окрім країн, які відвідав М. Пенс, значну увагу привертає Мексика, яка ще у часи передвиборчої кампанії Д. Трампа була топовою латиноамериканською країною у згадуваннях преси. В період передвиборчої агітації Трамп заявляв про будівництво стіни на кордоні між країнами, і що побудує її Мексика за свій кошт. 
Керівництво Мексики дуже насторожено відносилося до такого роду заяв, i виражало навіть подив в подібних закликах. Різкі заяви були зроблені на адресу керівництва Мексики про незаконну наркоторгівлю, i що саме стіна зможе зупинити несанкціонований продаж наркотиків. Президент США хоче запровадити нове законодавче регулювання, що стосується посилення мір стосовно незаконного перетину кордону між Мексикою, та змінити стратегію міграційної політики держави в цілому.

Також потрібно відмітити, про заяву Д. Трампа щодо перегляду взаємовідносин Північноамериканської угоди про вільну торгівлю, і потребу «повного повторного обговорення», участі в організації НАФТА Мексики та Канади, інакше США вийдуть 3 неї. Перехід від філіального виробництва, які знаходяться на території Мексики, до США, може призвести до значної втрати робочих місць в Мексиці, та скоротити наповненість бюджету країни.

Пріоритетною темою міжнародної повістки та адміністрації Білого дому за останні два роки стали американо-кубинські відносини. Ця подія явилось знаковою не тільки для Вашингтону і Куби, а в цілому для всіх країн Західної півкулі та світової спільноти. Примирення 3 Гаваною, було гіперважливим рішенням Б.Обами, це був вмілий зовнішньополітичний хід, ретельно вивірений i розрахований на подальшу перспективу [5].

Ряд експертів, оцінюючи різкі заяви на адресу Р. Кастро зі сторони Д. Трампа оцінюють, як політику ізоляціонізму, яка вже не повинна мати місце в сучасному світі. Історичний візит, який здійснив у 2016 році Б.Обама на острів, а це був перший офіційний візит 31928 року був проривом американської дипломатії. В своєму виступі в м. Маямі Трамп підкреслив своє невдоволення політикою США щодо Куби, в період президентства Б.Обами, та підкреслив саме вороже ставлення до острова Свободи, критикуючи керівництво Куби за порушення прав людини, i заявив про відміну «односторонньої угоди», підписаною Б. Обамою.

Вірогідність поступок 3 двох сторін являється сумнівною, як зазначає С. Уілкінсон відносини між Кубою та США на даному етапі характеризуються як такі, що зайшли в глухий кут. 3 одного боку, Вашингтон не скасує санкції, поки на Кубі зберігається однопартійна система 3 плановою економікою. 3 іншої сторони, Гавана не відмовиться від своєї політико-економічної системи, поки не будуть зняті санкції [7].

Низка експертів вважають, що саме кроком назад у відносинах США та Куби, стали заборона на поїздки до Куби американців, фінансових операцій 3 різноманітними підприємствами, але раніше вже ряд санкцій та обмежень були зняті з Куби, які були зняті та запрацювали, і діють на Кубі США не стане знову забороняти.

Найболючішою темою у відносинах з США $є$ Венесуела, яка знаходиться в важкому політичному, економічному та соціальному становищі, де кожен день відбуваються масові протести та опозиційні сили країни вимагають відставки нині діючого президента Н. Мадуро. Д. Трамп 12 серпня 2017 року, зазначив, що є багато можливостей вирішення політичної кризи, однак, саме військове вирішення питання цілком ймовірно. Такі різкі заяви з боку США, були прокоментовані венесуельською стороною, як посягання на суверенітет держави i порушення міжнародного права та Уставу ООН. При цьому М. Пенс заявив, що США використовують всю свою економічну та дипломатичну владу у вирішенні конфлікту в Венесуелі, і їі може виявитися недостатньою. 
Таким, чином можна прогнозувати що в перспективі відносини між США та деякими країнами Латинської Америки покращаться, зокрема 3 Аргентиною та Бразилією. Два регіональні гіганти, які задають тон у зовнішньополітичних стратегіях країн континенту, можуть стати навіть союзниками США. Аргентина вже стала на шлях зближення та залучення американських інвестицій, і прийняттям нової доктрини зовнішньої політики своєї держави у 2015 році. Що стосується Бразилії, то поки вона зайнята вирішенням питання внутрішніх проблем в державі до виборів президента країни у 2018 році.

Найбільше 3 усього регіону може постраждати Мексика, яка надто від американської економіки, і наповнення ії бюджету залежать від багатьох факторів залежності від США. Ревізія угоди про зону вільної торгівлі, може взагалі привести до економічного колапсу в країні.

Найгостріше ситуація наразі з Венесуелою, адже загострення конфлікту може призвести до військової інтервенції, проти чого виступають всі країни Латинської Америки. Також потрібно зауважити, що інтерес Росії та зобов'язання, які має Венесуела перед Росією також значні. I військове втручання може привести до загострення відносин США з Росією. Для Куби військове вирішення питання у Венесуелі теж може бути фатальним, адже Куба купує венесуельську нафту, i енергозалежна від неї. Фундаментальні прогнози стосовно відносин США та країн Латинської Америки при новій адміністрації, поки що робити зарано, однак вже зроблені деякі кроки, які в перспективі стануть пріоритетними.

\section{Список використаних джерел та літератури}

1. Астахов Е. Латиноамериканское «ближнее зарубежье» США при администрации Д.Трампа [Электронный ресурс] / Е. Астахов // Международная жизнь. - 2017 // Режим доступа: https://interaffairs.ru/news/show/18579

2. Сударев В. П. Что ждать Латинской Америке от Дональда Трампа / В.П. Сударев // Латинская Америка. - № 2. - 2017.

3. Ткач О. М'яка сила як інструмент непрямого управління міжнародними процессами [Електронний ресурс] / О. Ткач, А. Ткач // Американська історія та політика. - № 2. - 2016 // Режим доступа: http://www.americanstudies.history.knu.ua/2-2/

4. Яковлев П. П.«Эффект Трампа» или Конец глобализации?: монография / П.П. Яковлев. Москва: РУСАЙНС, 2017. - 144 с.

5. Яковлев П. П. Президентство Б. Обамы: предварительные итоги [Електронний ресурс] / П. П. Яковлев // Режим доступа: http://www.perspektivy.info/oykumena/amerika/prezidentstvo_b_obamy_predvaritelnyje_itogi_2016-0829.htm

6. Weeks G. The Trump Doctrine in Latin America [Електронний ресурс] / G. Weeks. Foreign Policy \& U.S./ Latin America Relations // Режим доступа: https://theglobalamericans.org/2017/08/trump-doctrine-latin-america/

7. Wilkinson S. A Perfect Impasse? Cuba's Move Towards the Market and the United States' Move Towards Cuba S. / Wilkinson S. // Economic Affairs. - 2017. - Vol. 37. - № 1. - P. 19-35.

\section{References}

1. ASTAHOV, E. (2017) Latinoamerikanskoe «blizhnee zarubezhe» SShA pri administratsii D.Trampa [Online] Available from: https://interaffairs.ru/news/show/18579 (Accessed December 8, 2017).

2. SUDAREV, V.P. (2017) / Chto zhdat Latinskoy Amerike ot Donalda Trampa / Latynskaya Ameryka. - № 2 .

3. TKACH, O., Tkach, A. (2016) M"yaka syla yak instrument nepryamoho upravlinnya mizhnarodnymy protsessamy [Online] Available from: http://www.americanstudies.history.knu.ua/2-2/ (Accessed December 8, 2017). 
4. YAKOVLEV, P. P. (2017) Effekt Trampa» ili Konets globalizatsii?: monogr. - Moskva: RUSAYNS.

5. YAKOVLEV, P. P. (2016) Prezidentstvo B. Obamyi: predvaritelnyie itogi [Online] Available from:

http://www.perspektivy.info/oykumena/amerika/prezidentstvo_b_obamy_predvaritelnyje_itogi_2016-0829.htm (Accessed December 8, 2017).

6. WEEKS G. (2017) The Trump Doctrine in Latin America [Online] Available from: https://theglobalamericans.org/2017/08/trump-doctrine-latin-america/ (Accessed December 8, 2017).

7. WILKINSON, S. A (2017) Perfect Impasse? Cuba's Move towards the Market and the United States" Move Towards Cuba S. Economic Affairs. Vol. 37. №. 1. P. 19-35.

Надійшла до редколегії 15.04.2018

Kateryna Vakarchuk, $\mathrm{PhD}$ in Political Sciences, Associate professor Odessa I. I. Mechnicov National University

\title{
POLICY OF THE D. TRUMP ADMINISTRATION IN LATIN AMERICAN COUNTRIES: PREDICTION AND PROSPECTS
}

\begin{abstract}
The article discusses the main changes of US foreign policy towards Latin American countries under the administration of D.Tramp. The new challenges and approaches to establishing relations between the countries of the Western countries are analyzed. A main visit to the countries of Latin America is considered by the representatives of the new administration of the USA, in particular Colombia, Argentina, Chile and Panama. Key issues of developing a common position on the crisis in Venezuela and the possibility of US military intervention on security issues, improving trade and economic cooperation and restoring democracy in Latin America.

The statements of analysis regarding the change of US policy towards Mexico relates to the construction of a new border in the form of a wall between two countries, the strengthening of measures on migration policy, the revision of the North American Free Trade Agreement and the positions of Mexico and Canada. The establishment of diplomatic relations between Cuba and the United States was met D. Tramp's critics. He said that he wouldn't continue to declare strategy of his predecessor until the leadership, the political regime of the Cuba and the restoration of the rights and freedoms of citizens will change on the island.

Change in the relations between Argentina and the US in connection with the arrival of the new president of Argentina, official visits between the presidents of both countries took place. As for Venezuela, the most urgent issue is because the United States seeks support from the continent's leaders for possible military intervention.
\end{abstract}

Key words: US, Latin America, foreign policy, relations, prospects

УДК 94:327.8 (73+729.1) «1959»

Катерина Касаткіна, аспірантка,

Запорізький національний університет

\section{СТАВЛЕННЯ ВАШИНГТОНУ ДО ПІСЛЯРЕВОЛЮЦЙНОЇ КУБИ (ПЕРШІ МІСЯЦ 1959 Р.)}

Анотація. У статті здійснена спроба проаналізувати ставлення Вашингтону до післяреволюиійної Куби у перші місяиі 1959 р. Окрім изього, представлена узагальнююча характеристика револючійних подій 1953 - 1959 рр., які вплинули на позицію Сполучених Штатів щэодо нового кубинського уряду. Проведено аналіз ключових проблем, які несли 